\title{
RE YELLOW CAB LTD. AND BOARD OF INDUSTRIAL RELATIONS
}

\author{
TIMOTHY J.CHRISTIAN*
}

\section{INTRODUCTION}

The decision of the Supreme Court of Canada in Yellow $C a b^{1}$ is of importance for two reasons. First, the court narrowly construed the statutory concept of employment and limited the scope of collective bargaining legislation in Alberta. Second, the court assessed and adjudged several interesting arguments about the ambit of judicial review of decisions of the Alberta Board of Industrial Relations. This comment will deal with both elements of the decision and will consider the impact of the recent decision of the Supreme Court of Canada in Olds College ${ }^{2}$ with respect to judicial review.

* With the Faculty of Law at the University of Alberta.

1. Re Yellow Cab and Board of Industrial Relations (1980) 114 D.L.R. (3d) 427.

2. The Alberta Union of Provincial Employees on Behalf of Branch 63. Edmonton. Alberta and The Public Service Employee Relations Board in and for the Province of Alberta and its Members v. The Board of Governors of Olds College, Olds, Alberta, unreported, June 23, 1982. In this case, the Public Service Employee Relations Board (PSERB) determined that certain issues in dispute between the Union and the College were arbitral and that certain others were not pursuant to s.48 of the Public Service Employee Relations Act, R.S.A.1980, c. P-33 (PSERA). The College sought an order in the nature of certiorari to quash the decision of the Board. H.J. McDonald J. granted certiorari. On ap. peal, the Court of Appeal reversed the trial judge in part but held that certain items the Board had declared to be artibral were non-arbitral.

The Supreme Court of Canada had to determine whether the Court of Appeal had correctly ruled that the items were non-arbitral. In approaching this task, the Supreme Court had first to establish the basis upon which courts could review decisions of the Board in light of the privative sections in the Act.

The PSERA contains privative sections substantially similar to those found in the L.R.A.. Section 9 grants the Board authority to make declarations about a wide range of matters and provides that such decisions are "final and binding". (Virtually identical to L.R.A. s.8 and A.L.A.s.50, infra n. 47.)

Section 11 provides that the Board has exclusive jurisdiction to exercise the powers conferred upon it and to determine all questions of fact or law and that such decisions are final and bindings, lidentical to L.R.A. s. 18(1), and A.L.A. s. 51(1), infra n. 48).

Section $\mathbf{8 9 ( 1 )}$ provides that no decision of the Board shall be reviewed in any court and that no proceedings shall be undertaken by way of injunction, declaratory judgment. prohibition, quo warranto or otherwise (virtually identical to L.R.A. s.18(2), and A.L.A. s.51(2), infra n. 48).

Section 89(2) provides that not withstanding $s .89(1)$ an application for certiorari or mandamus may be brought if filed with the court not less than thirty days after the date of the Board decision. Virtually identical to L.R.A. s.18(3), and A.L.A. s.51(3), infra n. 48). Laskin C.J., for the majority, held that the explicit provision for review in $\mathrm{s.89(2)}$ made it impossible to read s.9 or s.11 as creating immunity from judicial review.

In the face of this explicit provision for review [s. 89(2)] it is impossible to read it out of this statute or to subordinate it to ss. 9 and 11 or even to limit it to questions of jurisdiction in the strict sense, as urged by counsel for the Union and counsel for the Board.

In other words, the "final and binding" and "exclusive jurisdietion" privative clauses did not preclude review pursuant to $\mathrm{s}$. 89(2). This finding is consistent with the reasoning of the Court of Appeal in Uncle Ben's Tartan Breweries of Alberta v. Board of Industrial Relations of Alberta [1974] 4 W.W.R. 119.

Not withstanding the fact that the privative sections of PSERA do not preclude review for error of law the Chief Justice went on to create a restrictive standard according to which the presence of error is to be determined. He said at p. 4:

... IIf still remains to consider the scope of review on alleged errors of law, and it is my opinion that the commanding terms of $s .9(1)$ and especially of $s .11$ cast a gloss on 
In addition, the Alberta Labour Act, S.A. 1973, c. 33, (hereinafter referred to as the $1973 \mathrm{Act}$ ) which was in force at the time of the litigation, has now been repealed and replaced by the Labour Relations Act, S.A. 1980 , c. 72 (hereinafter referred to as the L.R.A.) and the Employment Standards Act, S.A. 1980, c. 62 (hereinafter referred to as the E.S.A.). This comment will briefly assess the legacy of Yellow $C a b$ in the new statutory environment.

\section{THE DECISION OF THE BOARD}

A. The Facts.

A union local attempted to organize a group of taxi drivers for the purpose of collective bargaining. The taxi company allegedly threatened two leaders of the organizing drive that they would be terminated unless they ceased their activities on behalf of the union. The union and the two leaders filed a complaint with the Alberta Board of Industrial Relations alleging that the taxi company had interfered in the formation of a trade union. $^{3}$

The allegation, if true, would have constituted a violation of one of the most important protections afforded to persons wishing to organize themselves for the purpose of collective bargaining. Labour legislation in

the extent to which decisions of the Board may be overturned by a Court. Certiorari, considered in the light of ss. 9(1) and 11, is a long way from an appeal and is subject to restriction in accordance with a line of decisions of this court which, to assess them generally, preclude judicial interference with interpretations, made by the Board which are not plainly unreasonable.

The effect of ss. 9 and 11 is to cast a gloss on the privative sections such that only plainly unreasonable interpretations may be quashed for error of law.

Laskin C.J. concluded that the majority of the Court of A ppeal had misapprehended the effect of McLeod v. Egan [1975] I S.C.R. 517 and Bradburn v. Wentworth Arms Hotel [1979] 1 S.C.R. 846 by deciding that no more curial defence was owed to the interpreta. tions of the Board of its constituent statute than would be owed to the interpretation by an arbitration board of a statute which becomes material in its deliberations. He said at p. 7:

Here the Public Service Employee Relations Board is operating in its home territory so to speak. It was concerned with the interpretation and application of provisions confided by its constituent Act to its exclusive administration, with its decisions to have final and conclusive effect. In such circumstances, the proper approach by a reviewing court is not the blunt substitution of judicial opinion for the views of the Board but rather that expressed by Dickson J. in Canadian Union of Public Em ployees v. New Brunswick Liquor Corporation [1979] 2 S.C.R. 227 at 237, where he formulated the issue of scope of review as follows:

Was the Board's interpretation so patently unreasonable that its construction can. not be rationally supported by the relevant legislation and demands intervention by the Courts upon review.

While the "linal and binding" and "exclusive jurisdiction" privative clauses do not preclude review. they underline the intention of the legislature to create an expert tribunal charged with the responsibility of construing its constituent statute. Decisions of the Board are not to be lightly interfered with and, indeed, may be reviewed only when the interpretation of the Board is patently unreasonable.

3. The complainants alleged a violation of s. 153 of the 1973 Act which provided as follows (s. 137 of the L.R.A.):

153(1) No employer or employer's organization and no person acting on behalf of an employer or employer's organization shall (a) participate in or interfere with the for. mation or administration of a trade union,..... (3) No employer or employer's organization and no person acting on behalf of an employer or employer's organization shall (a) refuse to employ or continue to employ any person or discriminate against any person in regard to employment or any term or condition of employment because the person (i) is a member of a trade union, ..... (d) seek by intimidation, or threat of dismissal or any other kind of threat, by the imposition of a pecuniary or other penalty or by any other means, to compel a person to refrain from becoming or to cease to be a member. officer or representative of a trade union... 
every Canadian jurisdiction extends a similar safeguard to those seeking trade union recognition. ${ }^{4}$ Without such a guarantee of immunity from employer recriminations, trade union organization would be much more difficult and the right to engage in collective bargaining would become illusory.

The Board convened a hearing to inquire into the complaint. The taxi company objected to the jurisdiction of the Board on the ground that the taxi drivers were not "employees", and therefore not entitled to the protection afforded by the Act. With the agreement of the parties, the Board decided to defer consideration of the alleged unfair labour practice pending its determination of the preliminary objection. The threshhold inquiry thus became whether the taxi drivers were employees.

The parties were able to agree on a statement of facts, ${ }^{5}$ and after considering the evidence and arguments of counsel, the Board concluded that the taxi drivers ought to be characterized as "employees".

4. Canada Labour Code, R.S.C. 1970, c. L-1, s.184 (3ka), as am.

British Columbia Labour Code, R.S.B.C. 1979, c.212, s.3(3).

Manitoba Labour Relations Act, S.M. 1972, c.75, s.7.

New Brunswick Industrial Relations Act. R.S.N.B. 1973, c. I-4, s. 3(2).

Nova Scotia Trade Union Act, S.N.S. 1972, c. 19. s. 51(3).

Ontario Labour Relations Act, R.S.0. 1980, c. 228, s. 66.

Prince Edward Island Labour Act, R.S.P.E.I. 1974, c. L-1, s. $9(1)$.

Quebec Labour Code, R.S.Q. 1977, c. C.27, s. 14, 15.

Saskatchewan Trade Union Act, R.S.S. 1978, c. T.17, s. $11(1$ Me).

5. The statement of facts follows:

a) The applicants drive a company-owned car which is rented from the company on a daily or weekly basis.

b) The company applies for and provides the Alberta registration and license plates,

c) The company applies for and provides the City of Edmonton taxi license.

d) The company pays for both of the above mentioned licenses.

e) Automobile insurance is paid by and in the name of the company,

i) The cars have the yellow and black colors of the company painted on them.

g) He may use stands set aside for the exclusive use of Yellow Cab Taxis as per Section $14(1)(a)$ of the Edmonton Taxi Cab By.Law.

h) The company pays the unemployment insurance contributions for each driver, based on a rate of $\$ 30.00$ per shift.

i) The company encourages drivers to wear Yellow Cab uniforms at three stands; the Edmonton Plaza, the Chateau Lacombe and the International Airport,

j) Due to the nature of the work there is little supervision necessary.

k) Gas is bought from the company.

I) Charge slips bear the company name,

$\mathrm{m})$ The company is responsible for collection of all charges,

nl A record consisting of name, address, photograph, license permit number, telephone number and driving record is kept of each company driver by the company.

of Discipline may vary for breaches of company rules but it may include termination.

p) The company pays for all expenses excluding gas but including oil and maintenance of atutomobile.

This description of the relationship was supplemented by testimony which established the following facts:

1. The rental rate which drivers paid for use of the company's cars was negotiated by the company and a drivers' association on an annual basis;

2. The general manager of the company was in charge of disciplining drivers in accordance with a system of graduated discipline which provided for the imposition of warnings, fines and termination;

3. The only money the company paid to the drivers was cash to reimburse them for charge slips. All other money earned by the drivers was collected by them from their passengers. From these monies, the drivers paid the company for vehicle rental:

4. The company had purchased exclusive taxi stand rights at the International Airport and at the major. hotels in the city. The company drivers were entitled to pick up passengers at these locations. The company enforced a strict dress code at these major stands. No individual drivers had stand agreements. 
B. The Statutory Background.

In order to properly discuss the Board's decision it is necessary to describe a few features of the 1973 Act. Unlike labour legislation in most Canadian jurisdictions, the 1973 Act was an omnibus statute which dealt with both labour standards and collective labour relations. ${ }^{6}$ Parts 2 and 3 of the Act dealt with labour standards, including minimum wages, vacation pay, and hours of work. Part 4 dealt with labour relations, including certification, collective bargaining and unfair labour practices. The Act contained a general definition section (s. 1) which was expressed to apply to the entire Act.

In this case, the Board was exercising its declaratory power pursuant to s. 50(1) to determine whether the persons in question were "employees". 8

\section{The Board Determines that Taxi Drivers are Employees.}

The Board was of the view that the definitions of "employer", "employee" and "wages" as found in the general definition section of the Act were not "exhaustive" and that it was necessary to look at the common law rules to determine whether an employment relationship existed..$^{9}$

6. In other jurisdictions, and in Alberta since the recent amendments to the labour legisla tion, there are two statutes - one dealing with minimum employment standards and the other with collective labour relations.

7. The general definition section (s.1) of the 1973 Act contained the following relevant definitions (s. 1 in the L.R.A.):

1. In this Act

(d) "employee" means a person employed by an employer to do work or provide services of any nature who is in receipt of or entitled to wages;

(e) "employer" means a person, corporation, partnership or group of persons who

(i) has control and direction over an employee, or

(ii) has control over the manner in which work or services are provided or done by an employee, or

(iii) is reponsible directly or indirectly for the employment of an employee, or

(iv) is responsible for the payment of wages to an employee;

(h) "wages" includes any salary, pay, overtime pay and any other remuneration for work or services howe ver computed, but does not include tips or other gratuities. [emphasis added]

8. The declaration section of the 1973 Act provided as follows (s. 8 of the L.R.A.):

50(1) The Board is empowered to decide for the purposes of this part whether: (a) a person is an employer; (b) a person is an employee; ... and the Board's decision is final and binding.

9. The relationship between the statutory and common law definition of employment was addressed by the Alberta Court of Appeal in R. v. Mac's Milk Limited [1973] 6 W.W.R. 598. In that case, Allen J.A. reviewed the statutory definitions and "equated" the words "employer" and "employee" with the words "master" and "servant". He then quoted Halsbury's discussion of the characteristics of the master-servant relationship and applied these "general principles" to the case under consideration. He also relied upon the four-fold test developed by Lord Wright in Montreal v. Montreal Locomotive Works Ltd. [1947] I D.L.R. 161 (P.C.). In short. Allen J.A. relied upon the common law notion of employment rather than the statutory definition. In my respectful submission, this was the wrong approach. Where special terms are defined by statute, it is not permissible to simply substitute the pre-existing common law concept. Rather, the court must give effect to the intention of the legislature by construing the new terms in their statutory context.

This approach was taken by Sinclair J.A., as he then was, in the Mac's Milk case. In his concurring reasons, Sinclair J.A. first reviewed the statutory definitions and commented at p. 615 as follows:

The definitions are broad. Indeed, in my view their scope is such that, for the purposes of the Act, they have affected, or perhaps replaced, many of the indicia that formed part of the usual common law tests.

As will become clear in this comment, the approach of Sinclair J.A. was preferred by the Court of Appeal and the Supreme Court of Canada in Yellow Cab. 
At first glance it might appear that the Board decided to substitute the common law definition of employment for the statutory definition. Such a manoeuvre would have been a reviewable, irrelevant consideration. On closer examination, however, it is clear that the Board looked to the common law definition not in lieu of examining the statute, but rather as an aid in construing certain elements of the statutory definitions that were left undefined by the statute itself. Thus the Board examined the common law notions of "control and direction" in defining "employer" in s. 1(e).

Based on the statute and common law, the Board framed four questions to assist it in determining the existence of an employment relationship. These were: (1) whether the opportunity to gain remuneration from the taxi-using public constituted the payment of wages to drivers; (2) who owned the business and equipment; (3) who had the right to make decisions regarding the equipment and credit discounts; (4) who had the right to make decisions regarding discipline.

In reviewing the evidence in light of these considerations, the Board found various indicia of employment. First, the Board found that the company provided the drivers with the opportunity to gain "remuneration" and that the actual monies paid thereby constituted "wages". In short, the Board found that: ${ }^{10}$

The Applicants looked to the business structure of the Respondent Company to produce the necessary revenue, so that the Applicants would, in the words of Section 1 (h) receive "any other remuneration for work or services however computed....

Second, the company retained ownership of the means of production, merely leasing the vehicles in accordance with a standard form rental agreement. The company also owned the licenses and maintained the cars. Third, the company retained an extensive degree of control over the drivers. The drivers were subject to taxi stand policy, dispatch policy and a disciplinary system of warnings, fines and termination. On these grounds, the Board found that the individual complainants were employees.

\section{THE SUPREME COURT TRIAL DIVISION REFUSES CERTIORARI}

The company brought an application for an order in the nature of certiorari before Dechene J., arguing that the Board had erred in law on a matter collateral to its jurisdiction by determining that the taxi drivers were employees and thus had exceeded its jurisdiction. " There are several decisions which support the proposition that the determination whether a person is an employee is a collateral question. ${ }^{12}$ In those cases, however, there was no "exclusive jurisdiction" privative clause such as

10. Alberta Union of Provincial Employees and Yellow Cab Ltd. v. Yellow Cab Taxi Drivers A ssociation [1978] 2 Can. L.R.B.R. 263 at 269.

11. Yellow Cab Ltd. v. Board of Industrial Relations, A. Sadownik, B. Dunbeck, Alberta Union of Provincial Employees and Yellow Cab Taxi Drivers Association 79 C.L.L.C. 14, 196.

12. In several cases it has been held that the determination of employment status is a matter collateral to the Labour Board's jurisdiction. Re Lunenberg Sea Products Ltd., Re Zwicker [1947] 3 D.L.R. 195; Labour Relations Board for British Columbia et al v. Canada Safeway Ltd [1953] 3 D.L.R. 641. 
existed in the 1973 Act. ${ }^{13}$ The effect of such clauses is to grant a tribunal exclusive jurisdiction to determine a matter that would otherwise be collateral to its jurisdiction. A matter which would have been preliminary to jurisdiction is brought within jurisdiction..$^{14}$

Mr. Justice Dechene was of the view that the question of whether the taxi drivers were employees was not collateral to the jurisdiction of the Board but within the jurisdiction of the Board by virtue of the exclusive jurisdiction privative clause. Further, the Board had not erred in law in determining that the taxi drivers were employees.

\section{THE COURT OF APPEAL DENIES THE APPEAL}

A. The Reviewability of Board Decisions.

Mr. Justice Clement wrote for the unanimous court..$^{15}$ He began by reviewing the privative clauses which protect decisions of the Board of Industrial Relations. Section 51(1) conferred exclusive jurisdiction on the Board to make final and conclusive decisions of law or fact in matters arising before the Board. ${ }^{16}$ Section 51(2) expressly prohibited the courts from issuing injunctions, declaratory judgments, or orders in the nature of prohibition or quo warranto against the Board. ${ }^{17}$ Section $51(3)$ relieved against the privative force of $s$. 51(2) and provided that decisions by the Board may be reviewed by applications in the nature of certiorarior mandamus if such applications were brought within thirty days of the Board decision..$^{18}$ The net effect of $\mathrm{s}$. 51 was that applications for certiorari or mandamus could be brought, provided proceedings were commenced in a specified time, for jurisdictional errors, including breach of the rules of natural justice and for errors of law on the face of the record.

Mr. Justice Clement relied upon the dictum of Martland J. in the Stedelbauer ${ }^{19}$ case as follows: ${ }^{20}$

The appellants, before this court, did not seriously dispute the conclusion of law reached by both

13. The exclusive jurisdiction clause contained in the 1973 Act (s. 51(1) ) provided as follows (L.R.A. S. 18(1) ):

The Board has exclusive jurisdiction to exercise the powers conferred upon it by or under this part and to determine all questions of fact or law that arise in any manner before it and the actual decision of the Board thereon is final and conclusive for all purposes, but the Board may, at any time, reconsider any decision, order, directive, declaration or ruling made by it and vary or revoke the decision, order, directive, declaration or ruling.

14. See S. Chumir, "Administrative Law - Privative Clauses - The Rammell and Farrell Cases" (1963) 3 Alta. L.Rev. 124.

15. Morrow and Leiberman JJ.A. concurred in the opinion of Clement J.A., 80 C.L.L.C. 14.011 .

16. Supra n. 13.

17. Section 51(2) provided as follows (L.R.A. s. 18(2) ):

No decision, order, directive, declaration, ruling or proceeding of the Board shall be questioned or reviewed in any court, and no order shall be made or process entered or proceedings taken in any court (whether by way of injunction, declaratory judgment, prohibition, quo warranto or otherwise) to question, review, prohibit or restrain the Board or any of its proceedings.

18. Section 51(3) provided as follows (L.R.A. s. 18(3)):

Not withstanding subsections (1) and (2), a decision, order, directive, declaration, ruling or proceeding of the Board may be questioned or reviewed by way of an applica. tion for certiorari or mandamus if an application therefor is filed with the court and served on the Board no later than 30 days after the date of the Board's decision, order. directive, declaration or ruling or reasons in respect thereof, whichever is later.

19. The Board of Industrial Relations of Alberta v. Stedelbauer Chevrolet Oldsmobile Ltd. [1969] S.C.R. 137.

20. Yellow Cab Ltd. v. Board of Industrial Relations 80 C.L.L.C. 14,011 at 52. 
the courts below. Their position was that the error in law by the Board would not warrant the quashing of its order because it did not relate to the Board's jurisdiction. In the present case, it was said, the Board's decision was in respect of the matter specifically referred to it by the statute and it could not be interfered with because, in reaching it, there had been an error of law.

I am not in agreement with this submission. The Alberta Labour Act does not contain a privative section, such as that contained in the British Columbia Workmen's Compensation Act, R.S.B.C. 1960 , c. 370, s. 76(1) referred to in a judgment of ths court in Farrell v. Workmen's Compensation Board (1962) 37 W.W.R.39, giving to the Board exclusive jurisdiction to determine all questions of fact and law and prohibiting removal of proceedings into any court by certiorari. The question, in this case, is as to the extent to which the proceedings of an administrative board may be reviewed by way of certiorari.

In my opinion such a review can be made, not only on a question of jurisdiction, but in respect of an error of law on the face of the record. That certiorari would issue to quash the decision of a statutory administrative tribunal for an error of law on the face of the record, although the error did not go to jurisdiction, was clearly stated in Rex v. Northumberland Compensation Appeal Tribunal; ex parte Shaw [1951] 1 K.B. 711... .

Mr. Justice Clement went on to define the position of the Board as follows: ${ }^{21}$

I wish to emphasize that in determining whether there has been an error in law we are not to extend to the Board the latitude of interpretation which has been granted to a tribunal to whom the Legislature has, by preclusive provisions, confided questions of law. In the circumstances of the present case, the law is to be pronounced and error determined by this court without the curial deference to the tribunal spoken of by Laskin, C.J.C. in McLeod et. al. v. Egan et. al. (1974) 46 D.L.R. (3d) 150 at 151-2.

The thrust of the court's decision was that the Board of Industrial Relations is vulnerable to the full range of judicial review provided that the statutory time limits are observed. It has no right to be wrong. The absence of an effective privative barrier allows the court to substitute its own definition for that proferred by the Board. The standard according to which the courts may intervene has recently been modified by the Supreme Court of Canada. In the Olds College case it was held that only patently unreasonable constructions would constitute reviewable errors of law. ${ }^{22}$

The decision of the Supreme Court of Canada in Stedelbauer, ${ }^{23}$ as adopted by Clement J.A., is widely accepted as the correct interpretation of the privative section. Stedelbauer leaves open an interesting argument that might not be readily apparent with respect to the remedies available on an application for judicial review.

The privative subsection (s. 51(2)) could at most serve to preclude review for error of law not going to jurisdiction. ${ }^{24} \mathrm{It}$ would not be effective to preclude review for jurisdictional defect, including breach of the rules of natural justice. It would, therefore, appear to be open to obtain any of the prerogative remedies and not just certiorari or mandamus, as provided by s. 51(3), to remedy an error going to jurisdiction including a breach of the rules of natural justice. It ought to be possible to bring an application for an order in the nature of prohibition to prevent the Board from committing a jurisdictional defect including a breach of the rules of natural justice, notwithstanding the purported exclusion of this remedy by ss. $51(2)$ and $51(3)$. Likewise, it ought to be possible to bring an application for a declaratory judgment or an injunction where such a jurisdic-

21. Id.

22. Supra n.2.

23. Supra n. 19.

24. Courts have consistently held that a privative clause such as in $\mathrm{s} .51(2)$ is not effective to preclude review for jurisdictional defect including breach of the rules of natural justice. See Toronto Newspaper Guild v. Globe Printing Co. [1953] 2 S.C.R. 18 and Jarvis v. Associated Medical Services Ltd. [1964] S.C.R. 497. 
tional defect is alleged. The court might refuse to exercise its discretion to grant these latter remedies in view of the existence of the equally effective remedies of certiorari and mandamus provided by s. 51(3). However, where the remedies of certiorari or mandamus were not available, because, for example, an application had not been filed within the thirty day time limit provided by s.51(3), it would still be open to a party alleging jurisdictional defect, including breach of the rules of natural justice, to proceed by way of an application for an injunction or declaratory judgment. Such a proceeding would circumvent the otherwise fatally effective time limit clause. Such an argument was contemplated by McDonald J. in Canadian Pittsburgh Industries. ${ }^{25}$

In that case, counsel had filed an application for certiorari of a Board decision beyond the thirty day time limit. The notice of motion alleged that the Board had committed an error of law and had declined to exercise its jurisdiction. Counsel argued that the privative clause in s. 51(2) could be effective only to preclude review for error of law on the face of the record. The time limit in s. 51(3) applied only to those certiorari applications founded upon error of law on the face of the record and did not apply to those certiorari applications which were founded upon jurisdictional defect including a breach of the rules of natural justice. The only effect of s. 51(3) was to relieve against the restriction imposed by s. $51(2)$ and, therefore, the time limit applied only to proceedings permitted by $51(3)$; i.e., applications for certiorari which alleged error of law on the face of the record.

This argument was rejected by Mr. Justice McDonald. He reviewed the judgment of Prowse J.A. in Uncle Ben's Tartan Breweries and said as follows: ${ }^{26}$

25. Canadian Pittsburgh Industries v. Board of Industrial Relations for Alberta and Inter. national Association of Bridge. Structural and Ornamental Ironworkers, Local 725 [1977] 3 Alta. L.R. (2d) 162.

The availability of the remedy of declaration, notwithstanding a "no certiorari" privative clause is examined by the British Columbia Supreme Court, per Hinds J., in Bailey v. Langley Local Board of Health, MacDonald and Attorney General of British Columbia [1982] 2 W.W.R. 76. In that case a privative clause purported to preclude review either by "certiorari or other writ of process into the Supreme Court." Observing that privative clauses will not necessarily preclude judicial review where a tribunal has exceeded its jurisdiction or failed to observe the rules of natural justice, Hinds $\mathrm{J}$. construed the privative section as not preventing review and went on to consider the merits of the declaration application.

The availability of injunctive relief notwithstanding the existence of prerogative remedies was considered by the Saskatchewan Court of Appeal in Regina (City) and Regina Board of Police Commissioners v. Regina City Policemen's Association and Sherstobitoff [1982] 1 W.W.R. 759. In this case injunctive relief was sought to prevent the Chairman of the Saskatchewan Labour Relations Board from appointing an arbitration board. Chief Justice Bayda, for a unanimous court, was of the view that an injunction could issue as a supervisory measure to restrain a public offical from exceeding his statutory jurisdiction and that it was not necessary to seek only prerogative relief in such circumstances. At p. 763 he said:

Justice should not suffer. If a situation, for example, warrants the grant of an order for prohibition to restrain an act, it can hardly be unjust to grant an injunction to restrain the same act. From the standpoint of convenience and practicality, it is no less convenient or practical and, in many cases, may indeed be more convenient and practical. Injunctive relief, for example, obviates the need to observe the strict differentiation between judicial and quasi-judicial acts, on one hand, and administrative acts, on the other.

A recent review of the law pertaining to the issuance of declarations is to be found in the Supreme Court of Canada judgment in Solosky v. The Queen [1980] 105 D.L.R. (3d) 745 at 753.

26. Id. at 170 . 
He [Mr. Justice Prowse] . . found in what was then s. 71(3) and is now, in identical wording, s. $51(2)$... . 'In my view, subs. (4) referred only to subs. (2) and subs. (3) to make it clear that those subsections did not affect remedies by way of certiorari or mandamus with respect to matters dealt with by the Board under Part 4 of the Act."

I interpret those words to mean that so far as subsection (2) may have reduced what otherwise would have been the scope of certiorari or mandamus, subsection (3) restores those remedies to their full potential. As far as certiorari is concerned, this must mean that error of law on the face of the record remains as a ground for relief.

However, Prowse J.A. did not discuss the effect of the time limit in what is now section 51(3), as the issue was not before him. In that respect, as I have said, the limitation must be enforced. Thus even if section $51(3)$ does preserve the scope of certiorari despite section 51(2), it does so only within a time limited by section $51(3)$.

In other words, McDonald J. construed the time limit clause as restricting the relief available wherever the remedy of certiorari was sought, regardless whether the alleged defect was jurisdictional or merely error of law on the face of the record.

Mr. Justice McDonald then suggested two limitations on the preclusive effect of the time limit provision. First, the limitation created by the combined effect of ss. 51(2) and 51(3) might not apply if it were alleged that the Board lacked constitutional jurisdiction under sections 91 or 92 of the B.N.A. Act. ${ }^{27}$ Second, a declaration could issue notwithstanding the time limit clause where it was demonstrated that the Board's decision suffered from a jurisdictional defect or a breach of the rules of natural justice. Mr. Justice McDonald posed this alternative in following terms: $:^{28}$

It is not for me to speculate now whether, on the facts of this case, the principle stated in Barnard $v$. National Dock Labour Board. [1953] 2 Q.B. 18, would apply - that is whether this would be a proper case for declaratory judgment in favour of the present applicants if they were to sue for such relief because they would otherwise be without a remedy for an injustice.

The basis for the dictum of McDonald J. was set out by Lord Denning in his review of the power of courts to issue declarations in the Barnard case. ${ }^{29}$ In that case, Lord Denning said: ${ }^{30}$

Finally, Mr. Paull said (and it was his principal argument) that these courts have no right to interfere with the decisions of statutory tribunals except by the historical methods of certiorari. He drew an alarming picture of what might happen if once the court intervened by way of declaration and injunction. It meant, he said, that anyone who is dissatisfied with a decision of the tribunal could start an action in the courts for a declaration that it was banned, and thus, by a side wind, one could get an appeal to the courts in cases where Parliament intended that there should be none. I think that there is much force in Mr. Paull's contention; so much so that I am sure that in the vast majority of cases the courts will not seek to interfere with the decisions of statutory tribunals; but that there is power to do so, not only by certiorari, but also by way of declaration, I do not doubt. I know of no limit to the power of the court to grant a declaration except such limit as it may in its discretion impose upon itself; and the court should not, I think, tie its hands in this matter of statutory tribunals. It is axiomatic that when a statutory tribunal sits to administer justice, it must act in accordance with the law. Parliament clearly so intended. If the tribunal does not observe the law, what is to be done? Remedy by certiorari is hedged around by limitations and may not be available. Why then should not the court intervene by declaration or injunction? If it cannot so in. tervene it would mean that the tribunal could disregard the law, which is a thing that no one can do in this country.

In Barnard, Lord Denning was not dealing with a time limit privative clause. There is in principle, however, no reason why a declaratory judgment cannot effectively circumvent the time limit clause in s. 51(3). The time limit applies only to applications for certiorari and mandamus. While

27. In the era ushered in by the Charter of Rights and Freedoms, it is arguable that the time limit privative clause would not be effective to preclude review of a Board decision which infringed or denied a right or freedom guaranteed by the Charter.

28. Supra n. 25 at 171.

29. Barnard v. National Dock Labour Board [1953] 2 Q.B. 18.

30. Id. at 41 . 
s. 51(2) purports to prevent the courts from granting declaratory relief, as noted above, this clause could only be effective to prevent declarations from being granted where an error of law not going to jurisdiction is alleged.

While no legal barrier stands in the way of such an application, there is an important practical consideration. The courts have an inherent discretion to refuse equitable relief where an equally effective alternative remedy provided by statute has not been sought within the time limit. Counsel would, therefore, have to justify failure to observe the time limit and demonstrate an injustice which would compel favourable exercise of the discretion. ${ }^{31}$

\section{B. The Court of Appeal Agrees that}

Taxi Drivers are Employees.

Before the Court of Appeal, counsel for Yellow Cab argued that the Board had erred in law in construing the relevant definitions in the 1973 Act. Mr. Justice Clement reviewed the Board's decision and rejected the contention of the appellant.

He first observed that the definition section used the directive "means" in relation to "employer" and "employee", and "includes" in relation to "wages". After examining a passage from Maxwell's Interpretation of Statues (12th edition) dealing with the use of "means" and "includes" in definition sections, Clement J.A. observed: ${ }^{32}$

Thus the meaning to be attributed to the words "employer" and "employee" is restricted to the
judicial interpretation of the statutory words of definition, while the meaning of "wages" extends
beyond its ordinary sense to include such things as are added by judicial proper interpretation of
the words in the statutory definition. I emphasize that the natural meanings of the words used in
definitions are themselves, unless the context otherwise requires, to be taken as commonly
understood by the persons intended to be affected by the operation of the statute. In this case, Part
4 affects generally labour relations between employers, trade unions and employees and many of
its provisions create rights and obligations between such persons or parties unknown to the
common law.

In other words, the term "wages" was to be defined as would be understood by the persons to whom Part 4 of the Act applied. The Board was free to construe the term "wages" so as to give the expression meaning in the context of collective labour relations rather than the law of master and servant and to broaden rather than narrow the scope of protection afforded to persons attempting to form trade unions.

Mr. Justice Clement concluded that the Board had not attributed a wider meaning to the term "wages" than intended by the legislature, as he states: ${ }^{33}$

It cannot be successfully contended that in the end result the activities of the complainants in forwarding the real business interests of Yellow Cab did not result in service to it of some nature hav. ing regard to the entire scheme and manner in which it was performed. The concept of "wages" is by the statutory definition extended to "any other remuneration for work and services however computed."

\section{THE SUPREME COURT OF CANADA ALLOWS THE APPEAL}

\section{A. The Reviewability of Board Decisions.}

The company appealed the decision of the Court of Appeal to the

31. The principles which ought to govern the exercise of judicial discretion to grant prerogative relief are dealt with by D.P. Jones in "Discretionary Refusal of Judicial Review in Administrative Law" (1981) 19 Alta. L. Rev. 483.

32. Yellow Cab Ltd. 80 C.L.L.C. 14,011 at 53.

33. Id. at 55 . 
Supreme Court of Canada which reversed all three lower bodies. $\mathrm{Mr}$. Justice Ritchie wrote for the unanimous court and began with a consideration of the jurisdiction of the Board.

It will be recalled that the Board was exercising its declaratory power pursurant to s. 50(1) to determine whether or not the complainants were "employees". This consideration was not merely incidental to the Board's jurisdiction to deal with the alleged unfair labour practice: rather, the Board was proceeding under a separate head of authority to decide whether the complainants were employees for the purposes of the Act. The Board's decisions on such questions were expressed to be "final and binding." ${ }^{34}$ The position taken by counsel on Appeal was that: $:^{35}$

... decisions ... made under the authority of this section were to be treated as final and not subject to appeal and ... the terms of the section were tantamount to a privative clause only subject to attack on the ground of lack of jurisdiction.

If accepted, this argument would have meant that the "final and binding" privative clause contained in s.50(1) would have precluded review for error of law on the face of the record. This would be so because the a vailability of the remedy of certiorariarises only as a result of s. 51(3) and this subsection in turn only overrides the privative effect of ss. 51(1) and $51(2)$. In other words, the relief of certiorari and mandamus provided in s. 51(3) is not expressly extended to s. 50(1) and the latter section ought to have full privative force. If this point had been accepted, the court would have had no choice but to defer to the decision of the Board taken under s. 50 unless a jurisdictional error arose. The alleged error of law within jurisdiction would have remained immune from review.

The court did not accept the argument. Mr. Justice Ritchie was satisfied that the remedy of certiorari available under s. 51(3) extended to determinations under $s$. 50 . Therefore, the court had jurisdiction to review decisions taken under the declaratory section (s. 50) for error of law on the face of the record. A similar argument was advanced and rejected in Olds College. ${ }^{38}$

While the approach taken by Ritchie J. proceeds logically from the wording of s. 51(3), it might be inferred that if s. 51(3) did not expressly or by implication extend the remedy of certiorari to decisions made under s. 50 , the privative formula employed in $\mathbf{s .} 50$ would be effective to preclude review for errors of law on the face of the record. Such an inference would be contrary to authority.

In an earlier case, the Court of Appeal of Alberta arrived at the same conclusion as the Supreme Court of Canada but chose a more direct route. In Uncle Ben's Tartan Breweries, ${ }^{37}$ Prowse J.A. considered a similar argument mounted in respect of a similar provision in the Alberta Labour Act, R.S.A. 1970, c. 196. It was argued that because the equivalent of $s$. $51(3)$ expressly referred to only the equivalent of ss. 51(1) and (2), the remedy for judical review did not apply to the declaratory power because it was protected by a separate "final and conclusive" privative enactment. Based on this argument, it was submitted that decisions of the

34. Supra $\mathrm{n} .8$.

35. Yellow Cab Ltd. v. Board of Industrial Relations, Sudownick, Dunbeck, Alberta Union of Provincial Employees and Yellow Cab Drivers' A ssociation [1980]24 A.R.275 at 279.

36. Supra n. 2.

37. Supra n. 2. In the $1970 \mathrm{Act}$, the power which the Board enjoyed pursuant to s. 50 of the 1973 Act (i.e., the declaratory power) was found in the same section as the precise equivalent of s. 51(1), (2) and (3) (i.e., the privative sections). 
Board pursuant to the declaratory power were not reviewable for error of law on the face of the record but only for jurisdictional defect including breach of the rules of natural justice.

This argument was firmly rejected by Prowse J.A. who said: $:^{38}$

A long line of authorities makes it clear that general words such as "final", "final and conclusive" and "final and binding" do not oust the jurisdiction of the court by way of certiorari.

In support of this proposition, Prowse J.A. quoted the dictum of Lord Denning in Regina v. Medical Appeal Tribunal; ex parte Gilmore: ${ }^{39}$

The second point is the effect of section 36(3) of the Act of 1946 which provides that "any decision of a claim or question ... shall be final." Do these words preclude the Court of Queen's Bench from issuing a certiorari to bring up the decision?

This is a question which we did not discuss in Rex v. Northumberland Compensation Appeal Tribunal, ex parte Shaw, because it did not there arise. It does arise here, and on looking again into the old books I find it well settled that remedy by certiorari is never to be taken away by any statute except by the most clear and explicit words. The word "final" is not enough. That only means "without appeal". It does not mean "without recourse to certiorari". It makes a decision final on the facts, but not final on the law. Notwithstanding that the decision is by a statute made "final". certiorari can still issue for excess of jurisdiction or for error of law on the face of the record.

Mr. Justice Prowse concluded that it was not necessary for the equivalent of s. 51(3) to expressly subject the declaratory section (the equivalent of s. 50(1) ) to the remedies provided under s. 51(3). This was so because the "final and conclusive" privative clause was not in itself effective to preclude judicial review for error of law on the face of the record. Such a clause merely emphasizes the fact that the legislature has not provided a means by which an appeal may be taken from the decision of the tribunal.

In Yellow Cab, Ritchie J. reviewed the privative sections of the Act and concluded: $:^{40}$

... there is therefore no privative clause when the remedy sought is certiorari and where, as in the present case, application therefor is filed and served no later than thirty days after the issue of the Board's decision. Hence the ability of this court and its powers to interfere with decisions are those which are outlined by Martland J. in [Stedelbauer]. ...

B. The Supreme Court of Canada Decides that Taxi Drivers are not Employees.

Having concluded that the privative sections were ineffective to limit the scope of judicial review, Ritchie J. went on to examine the substance of the Board's decision. He began by examining the definition of "employer". He noted the use of the directive term "means" and concluded that the statutory definition was exhaustive. He agreed with the Court of Appeal that the Board had not erred by "seeking assistance from the common law" in determining the meaning of the word "control".

Then, observing that "what is under consideration is "control and direction' over an employee," he went on to examine the definition of "employee". He reasoned that this definition is also exhaustive, and concluded that it "continues the meaning of 'employee' for the purposes of the statute to persons who are "in receipt of or entitled to wages."41

Mr. Justice Ritchie proceeded to hold that an employer-employee relationship can exist only where the employee is in receipt of or entitled to

\footnotetext{
38. Supra n. 2 at 131.

39. R. v. Medical Appeal Tribunali ex parte Gilmore [1957] 1 Q.B. 574 at 583.

40. Supra n. 35 at 281.

41. Id. at 283.
} 
wages, "the payment of which is the responsibility of the employer". ${ }^{42}$

The appellant had referred the court to several sections in the Act which illustrated wages flowing from an employer to an employee.$^{43} \mathrm{On}$ the basis of these examples, Ritchie J. concluded that the scheme of the Act " ... is predicated on the 'wages' therein referred to being wages which flow directly from an employer to an employee." 44

Having created a super-added requirement of wage-flow, Ritchie J. went on to consider the meaning of "wages". He examined the evidence to determine whether wages flowed from Yellow Cab to the taxi drivers. He found that the drivers were merely lessees of the company's cars and that they paid a fixed rental to the company for the use of the car, taxi stand, and dispatch facilities. Money was paid to the drivers by passengers, not by the company. There was no flow of wages between the company and the drivers and, therefore, no employment relationship.

\section{THE IMPACT OF THE YELLOW CAB DECISION}

The Supreme Court of Canada pronounced judgment in this case on October 7, 1980. On March 1, 1981, the Alberta Labour Act, S.A.1973, c. 33 was repealed and replaced by the Labour Relations Act, S.A. 1980, c. 72 and the Employment Standards Act, S.A. 1980, c. 62. The Labour Relations Act deals with collective labour relations and the Employment Standards Act with individual employment law and minimum standards of employment. It is therefore important to determine the effect of the Yellow Cab decision on the operation of the new Acts.

A. Who is an employee under the new Labour Relations Act?

The definitions have been changed in the L.R.A. and now provide as follows: ${ }^{45}$

1(k) "Employee" means a person employed to do work who is in receipt of wages, but does not include

(i) a person who, in the opinion of the Board, exercises managerial functions or is employed in a confidential capacity in matters relating to labour relations, or

(ii) a person who is a member of the medical, dental, architectual, engineering or legal profession qualified to practice under the laws of Alberta and employed in his professional capacity:

(1) "Employer" means a person who employs an employee;

(z) "Wages" includes any salary, pay, overtime pay and any other remuneration for work or services however computed but does not include tips and other gratuities.

42. Id. at 283. Section 1(e)liv) of the 1973 Act provided:

"Employer" means a person, corporation, partnership or group of persons who... (iv) is responsible for the payment of wages to an employee.

43. In the factum filed with the Supreme Court of Canada, the appellant referred to the following sections of the 1973 Act which illustrated wage-flow:

$s .13(1)(b)$ "The wages paid" (e) "wage rate" $(g)$ "the amount of money" (h) "the amount of money" $(k)$ "the amount of money"

s.16(1)(b) "wages paid" (e) "wages paid" (d) "vacation pay paid" (e) "money paid" s.30(1)(a) "fixing the minimum wages to be paid" (b) "fixing the minimum wages to be paid"

s.33(1) "computation of wages" (2) "employer shall pay to each employee" (3) "all wages earned by the employee shall be paid to him by the employer"

s.42(2) "fails to pay" or "fail to give ... money" occurs in each of these six subsec. tions.

Section 48 , priority to five thousand dollars.

Section 80 , deduction of payment to union.

It is submitted that all parts of the Act referable to "wages" are concerned solely with a "payment" by the "employer" to the "employee".

44. Supra n. 35 at 283.

45. Supra n. 16, 17 and 18 . 
Several differences between the 1973 Act and the L.R.A. must be observed. First, the definition of employee has been altered so that the words "to do work or provide services of any nature" have been deleted. This is a minor amendment which should have little effect. The very broad notion of "work" was not meaningfully expanded by these additional words. Second, ss. 1(i) and (ii) were formerly found in ss. 49(1) (h) (i) and (ii) of the 1973 Act. There is a change in location in the L.R.A. but no material difference in the substance of the managerial and confidential capacity exclusion and professional employee exemption. Third, the definition of employer has been markedly changed. All references to "control or direction" and the responsibility for employment or wage payment have been deleted. The definition of wages is unchanged.

Several implications arise from the comparison of the relevant sections. First, the absence of the requirement of control and direction will clearly allow the inclusion of persons considered independent contractors at common law within the scope of the L.R.A. Second, the removal of the requirement that the employer be responsible for the payment of wages undermines the basis upon which Ritchie J. proceeded in Yellow Cab. Now that employers are no longer statutorily responsible for the payment of wages, Ritchie J.'s super-added requirement of wage-flow has no statutory foundation. Third, a closely related point is that the sections in Parts 2 and 3 of the 1973 Act, upon which Ritchie J. relied as evidencing a requirement of wage-flow between an employer and employee, have been deleted from the L.R.A. and placed in the Employment Standards Act. There is, therefore, no basis for the inference that wage-flow is necessary. The only section which remains capable of supporting such an argument is s. 27 (s. 60 in the $1973 \mathrm{Act}$ ) which was one of the sections upon which the appellant based its argument in Yellow $\mathrm{Cab}^{46} \mathrm{It}$ is questionable whether this section, on its own, can be used to narrow the concept of employment as was done in Yellow Cab. The section empowers an employee to direct an employer to deduct union dues from his pay. It is not a mandatory requirement and if the system of wage payment were such as to make dues deduction inappropriate, s. 27 would not be violated.

In summary, the definition of employment has been broadened under the L.R.A. The impact of the Yellow Cab decision on the concept of employment has been reduced. Accordingly, a group of persons such as the Yellow Cab drivers, could now be certified notwithstanding the decision of the Supreme Court of Canada.

B. Who is an Employee under the new Employment Standards Act?

The definitions in the E.S.A. have been changed from those contained in the 1973 Act and the amendments are slightly different from the definitions in the L.R.A. The new E.S.A. provides as follows:

1(c) "Employee" means an individual employed to work who is in receipt of or entitled to wages and includes a former employee:

(d) "employer" means a person who employs an employee, and includes a former employer:

(t) "wage" includes salary, pay, commission or remuneration for work, however computed, but does not include

(i) overtime pay,

(ii) entitlements,

(iii) a payment made as a gift or bonus that is dependent on the discretion of an employer and that is not related to hours of work, production or efficiency,

(iv) expenses or an allowance provided in place of expenses,

(v) tips or gratuities,

46. Supra n. 43. 
(u) "works" includes providing a service.

The definitions of employer and employee are substantially similar to those contained in the L.R.A. The definition of wage is wider and is designed to extend the protection of the E.S.A. to persons receiving commission payment.

Given these broad definitions, it may be argued, along the same line as is advanced above with respect to the L.R.A. amendments, that the intention of the Legislature has been to expand the class of persons entitled to employment standards protection. It is not clear, however, that the courts will come to the same conclusion. This is so because the E.S.A. contains many of those sections formerly contained in Parts 2 and 3 of the 1973 Act, upon which Ritchie J. relied as evidencing the requirement of wage-flow between employer and employee. Given the Yellow Cab decision, the concept of employment may be narrower under the E.S.A. than under the L.R.A.

\section{What is the Scope of Judicial Review under the new}

Labour Relations Act?

The privative section protecting the declaration section (s. 8), has not been changed. ${ }^{47}$ The privative clauses contained in section 50 of the 1973 Act have been slightly modified. ${ }^{48}$ The formula employed in the L.R.A. is substantially similar to that used in the Public Service Employee Relations Act, R.S.A. 1980, c. P-33. The privative force of s. 18(2) is expressed to be subject to the right to judicial review contained in $s .18(3)$ in the L.R.A.

The amendment is of no great significance and should result in no change in the way in which the privative clauses are construed. Although s. $18(1)$ is not made expressly subject to s. 18(3), there is no inference that decisions covered by $\mathbf{s}$. 18(1) will be immune from judicial review. This is so for several reasons. First, decisions reached under s. 18(1) constitute decisions, orders, directives, declarations, rulings or proceedings of the Board, and pursuant to a literal reading of s. 18(3) are subject to review. This point is similar to that which was argued in Uncle Ben's Tartan Breweries. ${ }^{49}$ Second, even if s. 18(1) were to be given full privative effect it is important to recognize the limited notice the courts have taken of such

47. The declaratory part of s.8 of the L.R.A. provides as follows:

812) The Board may decide for the purposes of this Act whether: . . . and the Board's decision is final and binding.

48. Section 18 of L.R.A. provides as follows:

18(1) The Board has exclusive jurisdiction to exercise the powers conferred on it by or under this Act and to determine all questions of fact or law that arise in any matter before it and the action or decision of the Board thereon is final and conclusive for all purposes, but the Board may, at any time, reconsider any decision, order, directive. declaration or ruling made hy it and vary, revoke or affirm the decision, order, directive, declaration or ruling.

(2) Subject to subsection (3), no decision, order, directive, declaration, ruling or proceeding of the Board shall be questioned or reviewed in any court, and no order shall be made or process entered or proceedings taken in any court, whether by way of injunction, declaratory judgment, prohibit ion, quo warranto or otherwise, to question. review, prohibit or restrain the Board or any of its proceedings.

(3) A decision, order. directive. declaration, ruling or proceeding of the Board may be questioned or reviewed by way of an application for certiorarior mandamus if the ap. plication is filed with the court and is served on the Board no later than thirty days after the date of the Board's decision, order, directive, declaration or ruling or reasons in respect thereof, whichever is later.

49. Supra n.2. 
clauses. This section contains a "final and binding" privative clause, which on the authority of Prowse J.A. in Uncle Ben s Tartan Breweries, as discussed above, would not oust the jurisdiction of the court by way of certiorari for error of law whether going to jurisdiction or not or for jurisdictional defect including breach of the rules of natural justice. All a "final and binding" privative clause means is that there should be no appeal. The correctness of this analysis is confirmed by the Supreme Court of Canada decision in Olds College. Third, s. 18(3) is not necessary to grant the court jurisdiction to review decisions under s. 18(1). The court has an inherent power to grant prerogative relief. Even if $\mathrm{s}$. 18(3) is not construed as conferring power upon the court to grant prerogative relief, the Court's inherent jurisdiction would suffice.

Section 18(1) also contains an "exclusive jurisdiction" privative clause. As discussed above, these clauses are limited in their effect to bringing within jurisdiction matters which would otherwise be collateral to jurisdiction..$^{50}$ The effect of s. 18(1) would, therefore, be to make jurisdictional those matters which would otherwise be collateral to the Board's jurisdiction.

As the new Act has not changed the jurisdiction of the Board, the following summary of points considered above with respect to the Yellow $C a b$ and Olds College decisions should remain valid.

The Board has no power to err in law. The "final and binding" and "exclusive jurisdiction" privative clauses do not render the Board immune from review. They do, however, in combination with the other privative sections, impose a perimeter of patent unreasonability within which the Board may act with impunity. The Board's interpretation of its constituent statute will not be reviewed unless it is patently unreasonable.

In spite of s. 18(3), certiorari and mandamus are not the only remedies available where a jurisdictional defect, including breach of the rules of natural justice, is alleged. The remedies of prohibition, declaration and injunction remain available, subject to discretion. The time limit provision contained in s. 18(3) may be circumvented by the remedies of declaration or injunction where the ground for challenge is jurisdictional defect including breach of the rules of natural justice subject to discretion. 